\title{
Application of Synthetic Filters from Polypropylene in Diesel Locomotive Oil Systems to Improve the Efficiency of Cleaning Engine Oil
}

\author{
Oleksandr Babanin ${ }^{1}$, Oleksandr Butskiy ${ }^{1 *}$, Oleksandr Kovalenko ${ }^{1}$, Maksym Maksimov ${ }^{1}$ \\ ${ }^{1}$ Ukrainian State University of Railway Transport \\ *Corresponding author E-mail :toogarin94@ gmail.com
}

\begin{abstract}
The questions of application of synthetic materials as filtering, in oil systems of internal combustion engines are considered in the article. In existing oil systems, diesel engines of internal combustion use filtering elements that provide limited protection of oil systems from particles of potentially dangerous dimensions and, therefore, wear. They are not designed to work for a long service life with the higher level of oil purity required at the present time. The urgency of these issues is caused by the need to improve the quality of engine oil cleaning and, as a consequence, to increase the reliability of the engine. The use of filter elements made of porous, fibrous polypropylene is proposed. Which, according to the results of the experiment, will allow to extend the service life of the filter elements and improve the quality of their operation.
\end{abstract}

Keywords: Engine oil; Filtration; Fine Filter; Oil Cleaning; Synthetic Material.

\section{Introduction}

In connection with the high growth of freight turnover, the opening of new international transit corridors, the issue of further increasing the reliability and infallibility of the operation of all links of the transport complex is acute. First of all, this applies to vehicles that are directly involved in the process of cargo transportation, be it maritime, road or railway transport. Railway transport is the second, in terms of the number of goods turnover after the automobile, and high demands are placed on it for the safety and trouble-free operation of its operation. This is achieved by the effective use of its technical means, their qualitative repair, modernization. The introduction of new technologies, of course, increases the reliability of its operation.

In existing oil systems of diesel engines of internal combustion (ICE), filter elements are used that provide limited protection of oil systems from particles of potentially dangerous dimensions and, consequently, wear. They are not designed to work over a long service life with the provision of a higher level of oil purity that is currently required. [1].

Constantly growing requirements for ICE and as a result to the characteristics of filters complicate the task of engineers at all stages of design. Over the past decade, several major steps have been taken in the production of filter materials [2]. They helped in solving the problem of increasing the service life of the filter while ensuring an increased level of oil purity in oil systems. This article will consider the issues of the possibility of using synthetic materials in oil systems of diesel engines.

\section{Main Body}

\subsection{The Theoretical Part}

The root cause of premature failures of mainline locomotive ICE (Internal Combustion Engine) units and components is their abrasive wear. It is driven by wear products penetrating to oil during the ICE operation [3].

The oil filtration efficiency in oil systems is determined by the friction couple wear reduction index and also their contamination. Another important filtration index is an engine oil life cycle and filtering elements as such, the availability of impurities and wear products in the engine oil.

The process of impurities and wear products' accumulation in the engine oil will depend on two indexes: filtering element performance and purification efficiency.

In view of the foregoing it may be concluded that the oil filtration improvement can be reached upon the filtering element performance and efficiency increase. In the specific case with full-flow engine oil filters the mentioned issues are particularly topical. Thus, the increase of mentioned indexes for full-flow filters is the most reasonable in view of the reliability increase of ICE components' operation. The matter is that the complete oil flow further coming to friction couples is filtered during the full-flow operation [4].

During the filtering element operation its membrane is progressively contaminated resulting in the change of its screening efficiency, hydraulic resistance and filter capacity. In order to determine the index nature of change, in particular, the filter hydraulic resistance, it is required to consider laws of fluid filtration upon passing through the sieve obstacle [5]. 
The study of oil contamination [6] in different diesel engines allows concluding that the contamination process in normal operation, considering the filtration efficiency, corresponds the intermediary filtration law, when the filter supports particles on the membrane surface and its' internal channels' surface Figure 1 [7].
(A)

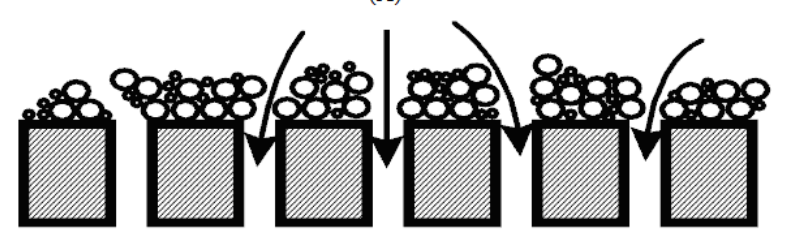

(B)

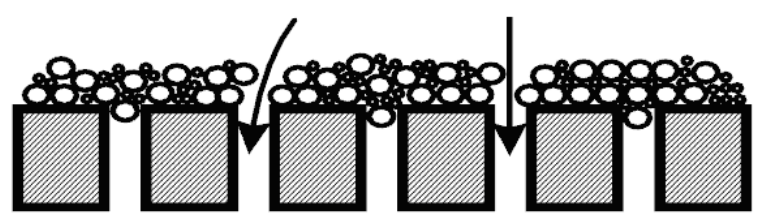

(C)

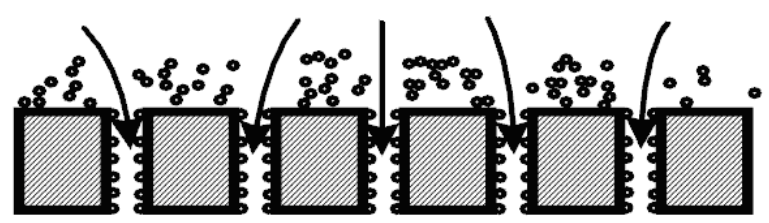

(D)

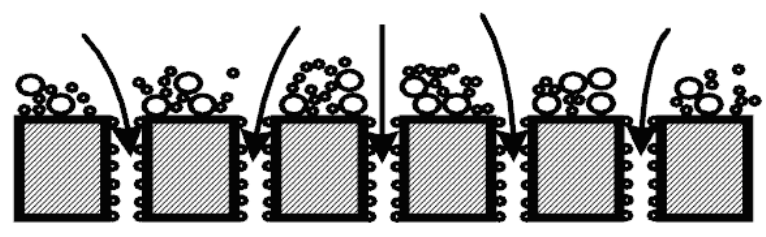

Fig 1 : Schemes of deposition of contamination particles on the filtering screen of the filter under different filtration laws: (A) to form a precipitate; (B) full clogging of pores; (C) with a gradual clogging of each pore; (D) intermediate

The principal filtration law is the Darcy's law. It establishes that the filtration rate is directly proportional to the pressure drop gradient and inversely proportional to the viscosity. Besides, the filtration rate depends on some coefficient called "The permeability" [3]. For flat filtering membrane the Darcy's Law is defined by the following (1):

$v_{\phi}=z \frac{\Delta p}{\delta \eta}$

Where: $v_{\phi}$ is the filtration rate, $\mathrm{cm} / \mathrm{s} ; \mathrm{z}$ is the permeability, $\mathrm{cm}^{2} ; \Delta p$ is the differential pressure, $\mathrm{g} / \mathrm{s}^{2} \cdot \mathrm{cm} ; \eta$ is the dynamic fluid density, $\mathrm{g} / \mathrm{cm} \cdot \mathrm{s} ; \delta$ is the thickness of the filter baffle, $\mathrm{cm}$.

Cake filtrations are mathematically characterized by the following equation (2). It expresses the dependence between the filtration time and the volume of contaminated fluid flowing through porous medium (body).

$$
0,5 k_{1} q=\frac{t}{q} \quad \frac{1}{v_{0}}
$$

Where: $q$ is the volume of the filtrate from the unit of the filtration surface, $\mathrm{cm}^{3} / \mathrm{cm}^{2} ; t$ is the filtration time, $\mathrm{s} ; v_{0}$ is the filtration rate at the initial moment, $\mathrm{cm} / \mathrm{s} ; k$ is the coefficient that takes into account the change in the resistance of the filtering wall.

The filtration according to the intermediary law is characterized by the fact that the suspension solid particles' caking is formed in pores and above the entry into porous channels. The filtration process is described by the following equation (3):

$k_{2} t=\frac{1}{v} \frac{1}{v_{0}}$

Where: $v$ is the average velocity of the fluid bing filtered, until the time $t, \mathrm{~cm} / \mathrm{s}$.

The following requirements are imposed on oil filters in accordance with the state standards [8]:

1. The filter shall qualitatively clean the engine oil from wear products and impurities. Along with such cleaning the filter shall not generate a significant hydraulic resistance to the engine oil flow:
2. During the whole life cycle the filtering element shall not change its capacity;

3. The simple replacement of filtering elements shall be ensured during the filter operation;

4. Filtering elements shall be strong and thermo-resistant by their mechanical and physical properties;

5. The filter shall have small dimensions, low weight and value;

6. Retain water and do not filter useful components of engine oil (additives);

7. The filter shall be harmonized and the filter service life shall not be less than the engine service life prior to overhaul;

8. During the whole service life the filtering element material shall not emit components to the engine oil flow.

Currently, simple indexes characterizing various properties of filtering materials are used for their quality evaluation [9]. The classification of simple quality indexes is shown on Figure 2.

However, the complex comparative assessment of filtering materials using simple indexes causes difficulties due to inconsistency of such indexes in the result of their different impact on oil products' refining [10].

In filtering material quality evaluation it is firstly required to determine the list of material properties and indexes characterizing such properties. Among physical and chemical properties are strength and contact properties that are determined by regulations and their values are set depending on filtering material application conditions.

Filtering material structure indexes play an important role in its application, directly affecting functions: filtrating, hydraulic and service life.

The permeability coefficient characterizes only properties of filtrating material and does not depend on filtration fluid properties, thus it is reasonable to use it as the criterion for filtering material quality evaluation [11].

The most informative filtering indexes are: filtration completeness, nominal filtration fineness and related filtering coefficient. Among service life indexes for the complex criterion for filtering material quality evaluation was 


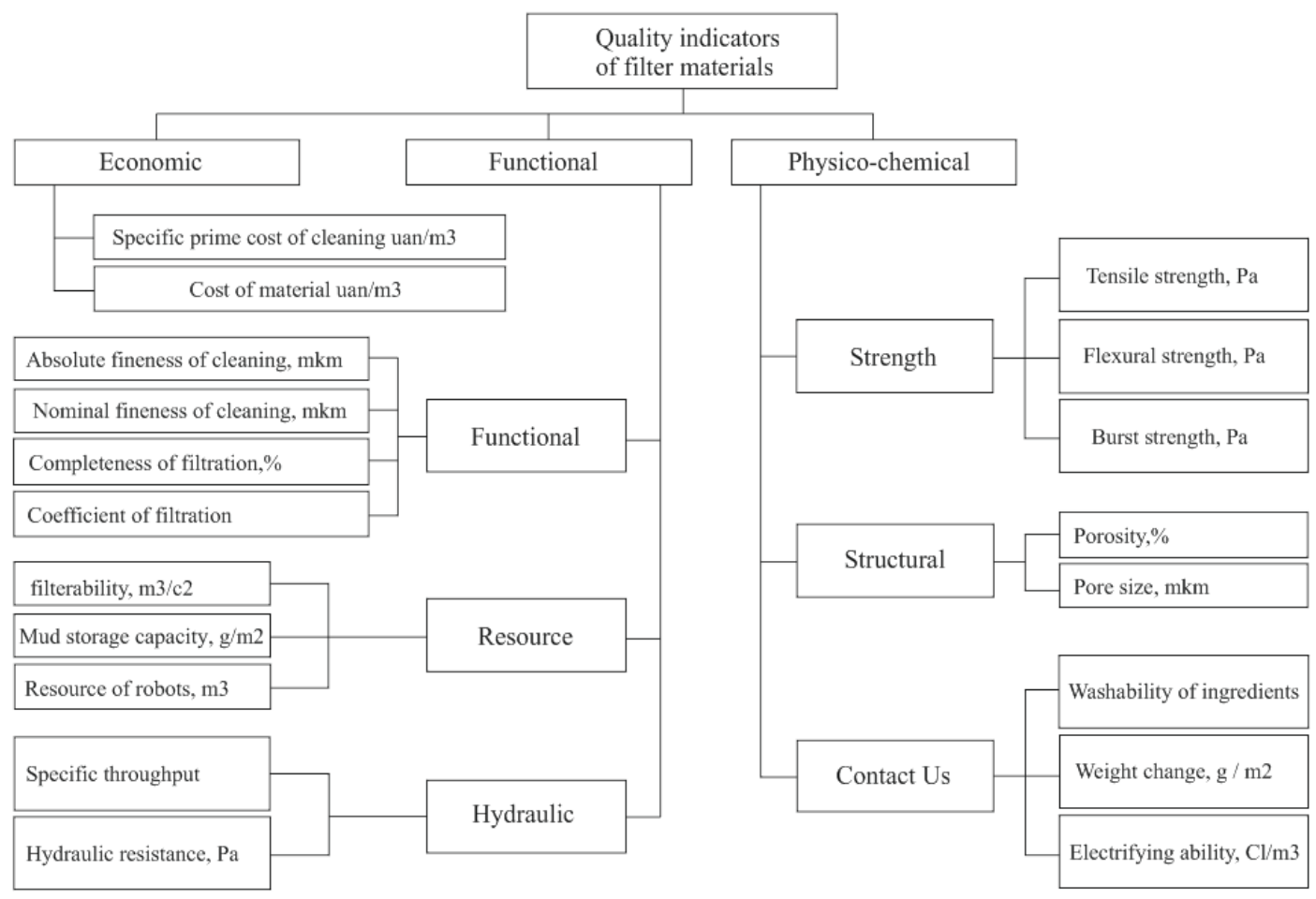

Fig 2: Classification of the quality of filter materials

selected the absolute index - the service life. In view of hydraulic indexes for filtering material quality evaluation was selected the specific capacity upon the set material hydraulic resistance.

Having studied filtration processes and requirements for oil filters, the preliminary analysis of synthetic material use for filtering elements can be made.

The bottom of modern materials for filtering elements is the material consisting of thin fibers of fixed size and geometry individual-

(A)

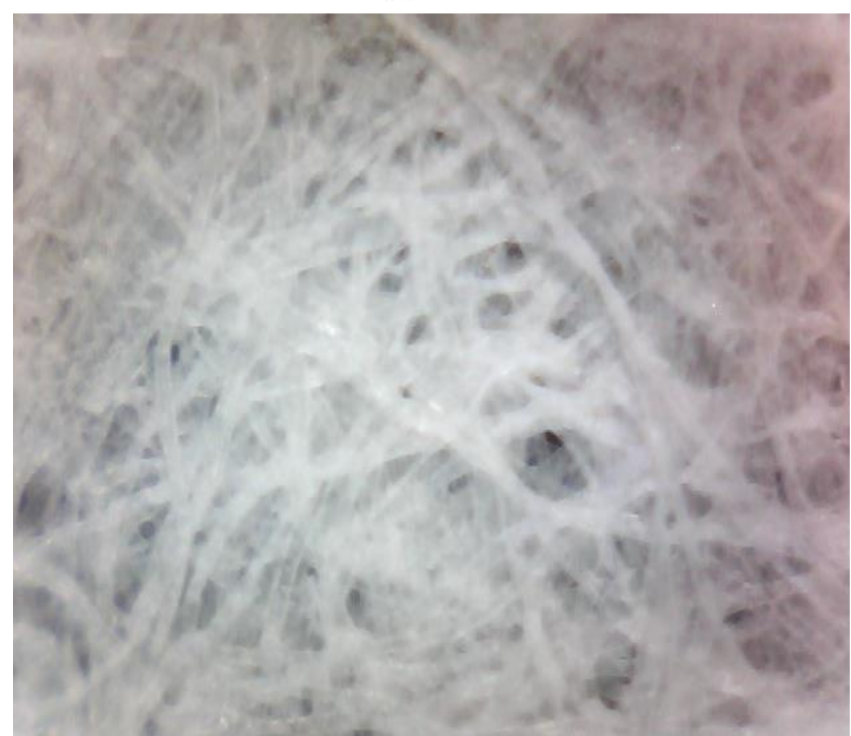

Fig. 3: Ratio of pores (voids) to the surface of fibers: synthetic filter material (A); paper filter material (B)
The second component of effective filter is the multilayer strucwith varying diameter that maximize the volume of voids in converging pore structure. It means that the filter internal surface provides the finer filtration than external surface that guarantees the uniform distribution of retained particles along the filter depth.

In the result the filtering element with the volume of voids bigger than the volume fibers has the higher dirt-holding capacture for complete use of material volume consisting of fibers ly binding them together. The material structure allows to ensure the bigger dirt-holding capacity and the lower pressure drop due to the large volume of pores. It also allows to retain hazard particulate matters.

The comparison of synthetic and paper filter pores is shown in Figure 3 [12].

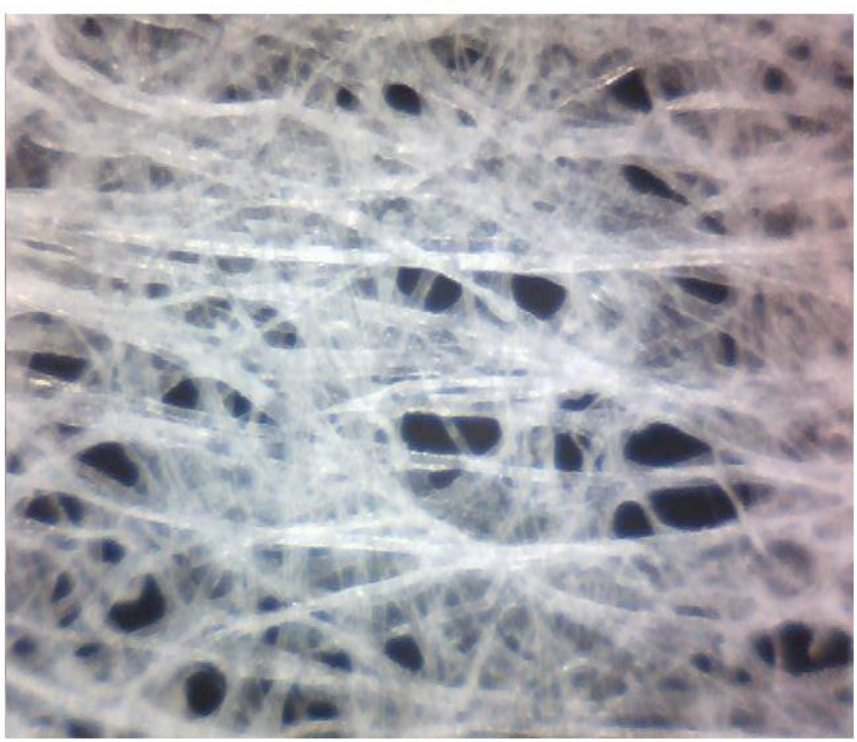

ity and is able to catch and retain the wider range of pollutants of bigger size. The efficiency of above-mentioned filtering elements significantly outweighs the efficiency of paper filtering element.

In order to manufacture sample filtering elements it was decided to use a porous fiber polypropylene.

Polypropylene is a synthetic thermoplastic non-polar polyolefin polymer. Depending on propylene polymerization conditions can be obtained polymers with different molecular structure that determines 
their physical and mechanical properties and, as consequence, their fitness for specific purpose [13].

Polypropylene is characterized by more complex molecular structure than the majority of industry polymers, as except monomer chemical composition, average molecular weight and molecular weight distribution, its' structure is affected by the configuration of pendent groups towards main chain. Technically it is the most important and perspective isotactic polypropylene. Deepening on type and ratio of existing stereoisomer's polypropylene properties vary in the wider range.

The polymer molecular structure impacts their ability to be processed by one or another method which, in turn, significantly determine the finished product properties.

In the assessment of polypropylene practice fitness for one or another purpose the primary importance goes to its mechanical properties. It is obvious that a polymer with low elasticity modulus, i.e. with low rigidity, cannot be recommended for manufacturing of technical parts to be subjected to high mechanical loads; in contrast the polymer with high rigidity is not applicable if the material has to observe high amplitude oscillations.

Polypropylene due to its paraffin structure is highly resistant to different chemical reagents' exposure even at high concentrations. Under normal temperature isotactic polypropylene properly resists organic solvent exposure even in case of longterm exposure.

Polypropylene fiber is the cheapest known type of synthetic fibers at the moment [13]. Such circumstance and also high feedstock availability for propylene fiber production in all advanced industrial countries contributed to its fast market entry. With further polypropylene production growth it can be expected that by selling price the polypropylene-based fiber will favourably compete with even the cheapest synthetic fibers.
At the moment polypropylene fiber is used for manufacturing of different technical items and consumer goods. The technically important sphere of its application is the manufacturing of filter fabrics possessing high rigidity, wear resistance and resistance to chemical reagent exposure and high temperature. They are better than polyamide and polyester fibers for many reasons. Such fabrics are not biologically decomposable and are fungus-resistant, making them reasonable to use in numerous industries, including machine building.

\subsection{Experimental Findings}

In order to conduct experimental studies a passenger mainline locomotive was chosen. In fine filters of this locomotive were installed 8 fiber polypropylene filtering elements. The feature of this locomotive oil system is the fact that fine filters are installed upstream coarse filters. It was made in order to clean the engine oil in case of fine filters' failure.

It shall be noted that the technical condition of mainline locomotive diesel engines degrades along with the locomotive mileage increase; it also depends on quality of current repairs, availability of qualitative spare parts, equipment and qualified personnel. Considering the actual technical condition of diesel engines approximately $90 \%$ of paper filtering element replacements is connected with contamination.

During fiber propylene filtering elements' operation laboratory analysis has shown as follows. The usage of these filtering elements has shown the preservation of both density during the engine oil filtration and porosity of filtering screen external layer. It allowed to ensure the fractional retention of foreign matters in engine oil.

During the whole period of service life of such elements the fine filters hydraulic resistance were constant due to formation of loose layer on the element surface. It also affected the filtering element service life to replacement.

The stages of the experiment on the use of filter elements from fiber polypropylene are given in Table 1 and Figures 4, 5.

Table 1: Parameters of experimental study stages

\begin{tabular}{|c|c|c|c|c|c|c|c|c|c|}
\hline Maintenance type & $\mathrm{MNT}^{*}-1$ & MNT-1 & MNT-2 & Oil change & MNT-1 & MNT-1 & MNT-1 & MNT-1 & MNT-1 \\
\hline Locomotive mileage, $\mathrm{km}$ & 1068 & 20143 & 30616 & 30616 & 39756 & 49044 & 59915 & 70147 & 80560 \\
\hline Filter pressure drop, $\mathrm{kg} / \mathrm{cm}^{2}$ & 0.9 & 0.95 & 1 & 0.9 & 0.95 & 1.05 & 1.2 & 1.35 & 1.5 \\
\hline Contamination, $1 / \mathrm{cm}^{-1}$ & 943.1 & 1347 & 1221 & 316 & 327 & 412 & 483 & 695 & 985 \\
\hline
\end{tabular}

* MNT-maintenance

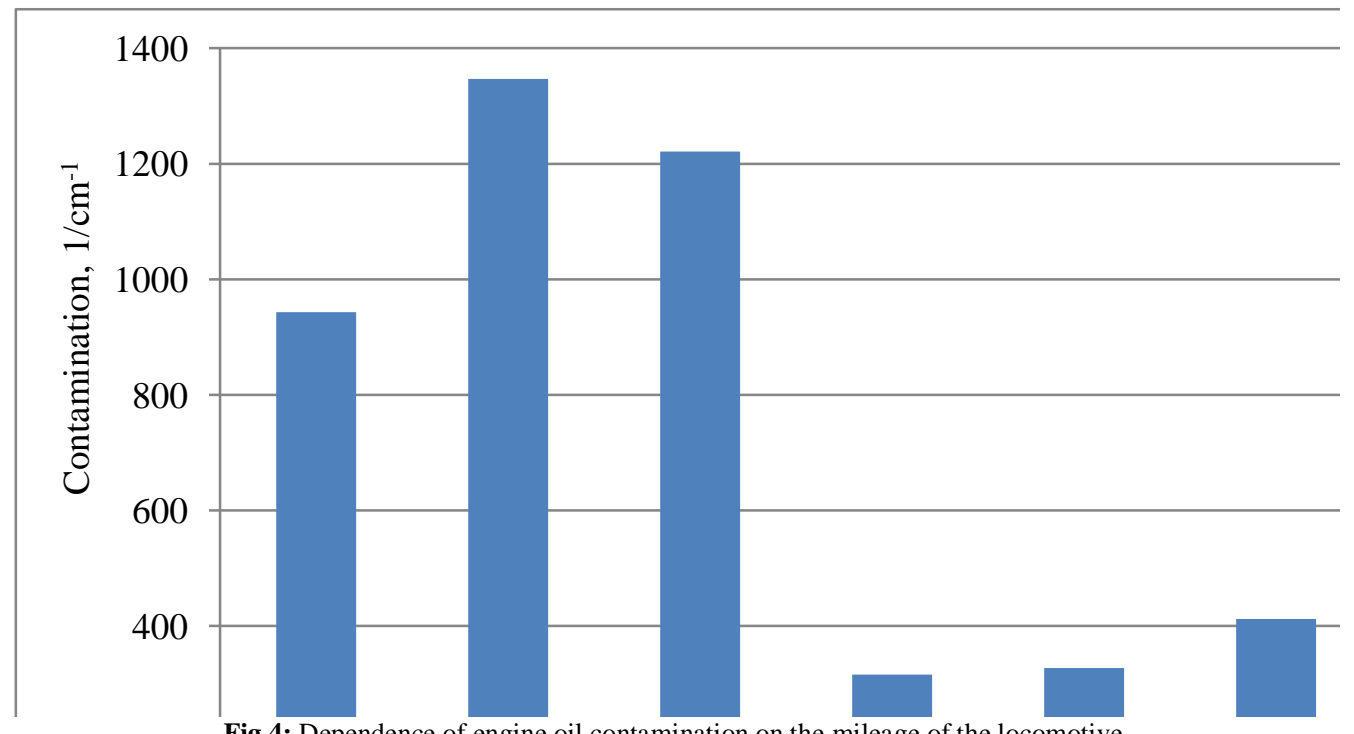

Fig 4: Dependence of engine oil contamination on the mileage of the locomotive 


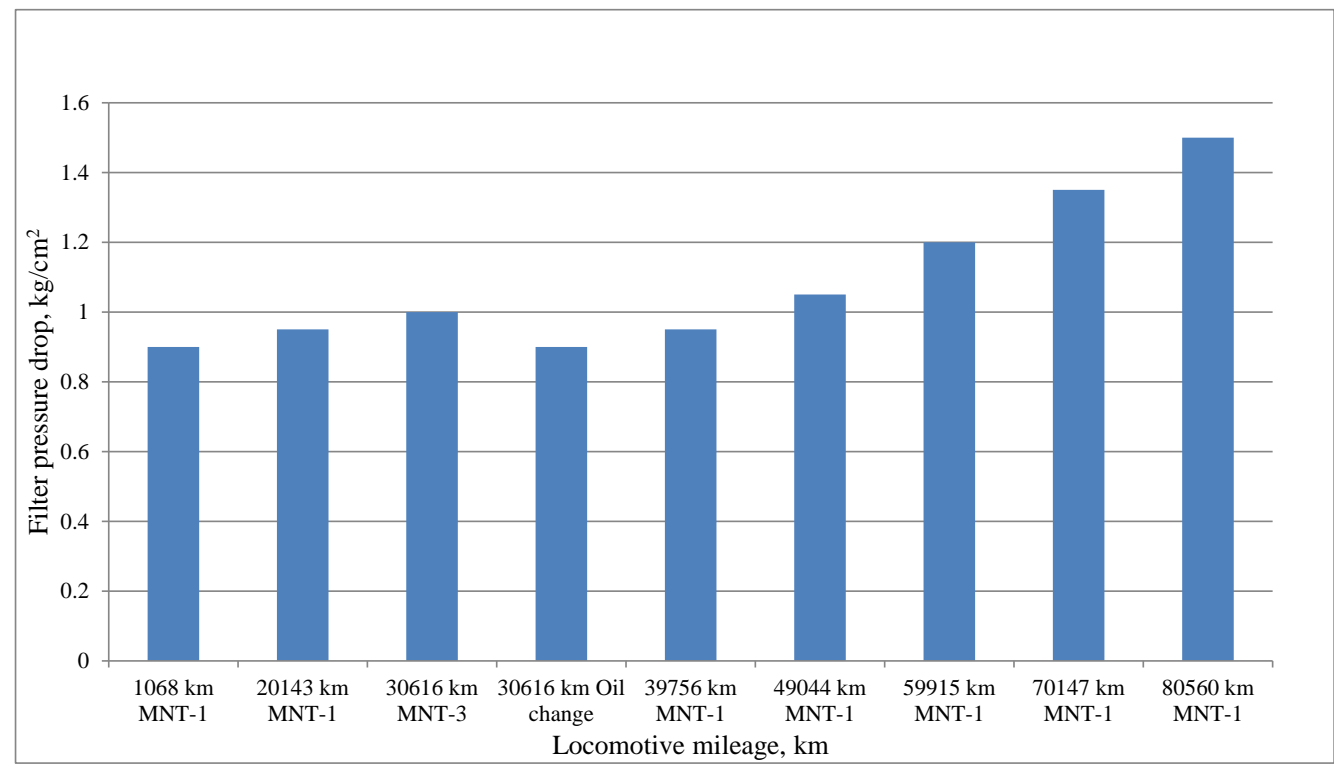

Fig 5: Dependence of differential pressure of engine oil on the filter from the run of the locomotive

\section{Conclusion}

Experimental studies have shown that the proposed fiber polypropylene filtering elements proved themselves as effective and qualitative for engine oil filtration.

Furthermore, such elements have low hydraulic resistance with the simultaneous preservation of required engine oil mechanical impurities filter capability.

Fiber polypropylene elements in comparison with paper elements possess the required mechanical strength and resistance to vibration and thermal loads.

Their design factors allow easy replacement during the maintenance or current repairs without changing the fine filter housing or oil system.

Considering the application of these filtering elements in view of the efficient use of resources, it shall be noted the following [14]. The production cost of these filtering elements is low and their service life is long, consequently, their use decreases expenses for their purchase and disposal. In the result the environment protection and cost saving issues are solved. It is particularly true in current conditions of austerity in our country.

\section{References}

[1] Samorukov V, "Tekhnologii filtratsii i razdeleniya PALL dlya avtomobilnoy tekhniki", 9-ya Mezhdunarodnaya avtomobilnaya konferentsiya «Dvigateli dlya rossiyskikh avtomobiley», No.9, Moscow, (2008), p.25-40, (in Russian),

[2] available online: https://www.hollingsworthvose.com/Documents/White\%20Papers/0821053\%20NANOWE B\%20WhitePaper.pdf, last visit:23.05.2018

[3] Vilbel B "The route to the high performance filter media", Hollingsworth \& Vose GmbH, No.39 (2008), pp. 2-4.

[4] Butskiy O Zastosuvannia syntetychnykh materialiv, yak filtruvalnykh $\mathrm{v}$ olyvnykh filtrakh teplovoznykh dyzeliv, Zbirnyk naukovykh prats UkrDUZT, No.174, (2017), pp. 42-50, (in Ukrainian), available online: http://csw.kart.edu.ua/article/view/127584 last visit: 20.05.2018

[5] Ovcharenko $\mathrm{S}$ "Modelirovaniye raboty i otsenka effektivnosti sistem ochistki motornogo masla razlichnykh seriy teplovozov", Vestnik RGUPS, No 1, (2006), pp. 21-26, (in Russian)

[6] Zhuzhikov V, Filtrovaniye: Teoriya i praktika razdeleniya suspenziy, Chemistry, (1980), pp. 26-42, (in Russian)

[7] Grigoev M, Ochistka v dvigatelyakh vnutrennego sgoraniya, Mechanical engineering, (1983), pp.35-54, (in Russian)

[8] Shevtsov Y, Vasilenko N, Bogdanov V, "Diagnostika tekhnicheskogo sostoyaniya dizelnykh dvigateley po parametram gidravlicheskogo soprotivleniya maslyanogo filtra", Nauchnyye trudy KubGTU, No.6, (2014), pp.3-7, (in Russian)

[9] State standard 22858-1977. Engines are autotractor. Elements of replaceable fine oil filters. Moscow, Standartinform Publ., (1977), pp.110, (in Russian)

[10] Kovalenko V, Krasnov A, Lesnoy K, "Kompleksnyye kriterii kachestva filtruyushchikh materialov dlya ochistki nefteproduktov na zheleznodorozhnom transporte", Nauka i tekhnika transporta, No 3, (2005), pp. 74-80, (In Russian)

[11] Majdana R, Tkaca Z, Abrahama R, Kollarovab K, Vitazeka I, Halenar M, "Filtration Systems Design for Universal Oils in Agricultural Tractors", Tribology in Industry, Vol.39, No.4, (2017), pp.547-558.

[12] Machal P, Majdan R, Tkac Z, Stancik B, Abraham R, Stulajter I, Sevicik $\mathrm{P}$, Raso $\mathrm{M}$, "Design and verification of additional filtration for the application of ecological transmission and hydraulic fluids in tractors", Acta universitatis agriculturae et silviculturae mendelianae brunensis, Vol.61, No.5, (2013), pp.1305-1311.

[13] Koutenev V, Samorukov V, "Kombinirovannyye mnogosloynyye materialy dlya vozdushnykh. toplivnykh i maslyanykh filtrov DVS s bolshim intervalom obsluzhivaniya”, Trudy «NAMI», No. 243, (2010), pp. 127-147, (in Russian)

[14] Ambrozh I, Ambrozh L, Belush D, Dyachik I, Janisch F, Manasik Z, Romanov A, Rovner I, Ryshchavy D, Shishko K, Shtirbany P, Tomis F Fedelem M, Forman Z, Freund L, Jambrich M, Polypropylen, Slovinské vydavatel'stvo odbornej literatúry, (1964), pp. 208-215.

[15] Tartakovskyi E, Kahramanian A, Aulin D, Basov O, Resursozberihaiuchi tekhnolohii ochystky system dyzelia ta teplovoza", Materialy 8-yi mizhnarodnoiu nakovo-praktychnoi konferentsii Suchasni enerhetychni ustanovku na transporti i tekhnolohii ta obladnannia dlia yikh obsluhovuvannia SEUTTOO-2017, Kherson, (2017), pp. 312-315, (in Ukrainian). 